\title{
Evaluating the Effect of Different Passive Cooling Techniques of Roofs on Energy Consumption in Buildings in Upper Egypt Using BIM
}

\author{
Nawal O. Ali ${ }^{1}$, Fatma O. Mohammed ${ }^{2}$, Mohammed H. Elhefnawy ${ }^{3}$ \\ ${ }^{1}$ Faculty of Technology and Education, Sohag University, Egypt \\ ${ }^{2}$ Faculty of Engineering, Sohag University, Egypt \\ ${ }^{3}$ Faculty of Fine arts, Assuit University, Egypt \\ (Corresponding author: Nawal_omar@techedu.sohag.edu.eg)
}

\begin{abstract}
The annual energy consumption rate in Egypt rises by $3.8 \%$ every year; traditional resources represent $92 \%$ of the generated energy. Taking into consideration the near depletion of their reserve and the included environmental issues with their use, it can be imagined that the energy situation in Egypt is disastrous. Therefore, improving the energy situation in Egypt became an urgent need. Reducing energy consumption in buildings, in particular, will help in reducing the overall consumed energy, since they consume $85 \%$ of the total energy production in Egypt. The design of roof slabs for thermal insulation purposes is required to reduce the energy consumed in buildings since they are accountable for $50 \%$ of the heat gain in a one-story building. By implementing passive cooling techniques, there are the chance to overcome the increased heat gain through roofs to reach the desired savings in energy. This search aims to evaluate the effect of different passive cooling techniques, applied to a student housing building's roof in Sohag University in new Sohag city in Upper Egypt, using building information modeling (BIM) platform. A review of the related scientific papers was carried out. Through this review, a matrix of 31 variables was conducted and applied to the building's roof. Energy consumption for every variable was calculated and compared to other variables. The findings proved that choosing the right passive techniques for roofs can help in reducing energy consumption by $46 \%$. Also, some of these techniques may have a small effect on energy consumption.
\end{abstract}

Keywords: Passive cooling; BIM; roofs; Upper Egypt

\section{INTRODUCTION}

Over the years, the increased use of air conditioning in buildings has led to a significant increase in energy consumption [1]. Buildings are responsible for more than $40 \%$ of world energy consumption and greenhouse gas emissions [2-4]. Because of the negative impacts of climate change and local weather phenomena such as Urban Heat Islands (UHI) and heat waves, it's expected that these percentages will increase more so in urban environments than in surrounding rural areas [2]. This indicates the urgent need for reducing energy consumption in buildings to stabilize the climate below the global average of $2{ }^{\circ} \mathrm{C}$ [3].

Buildings in Egypt consume $85 \%$ of the locally generated energy. $92 \%$ of this energy is from traditional resources. At the same time, renewable energy production and consumption are less than $2 \%$ as illustrated in Figure (1) [5]. Since 2011, Egypt faces a gap between its production and consumption of energy. This gap has increased over the years reaching 18 percent in 2018 as seen in Figure (2) [6], regarding the near depletion of this kind of energy source and the increased annual rise of its consumption, the current energy situation foreshadows a disaster. Thus, reducing energy consumption in Egypt in general and in building particular became an urgent need that all communities should help in improving it.

Energy consumption in buildings goes to three main purposes: electrical appliances, such as lighting, television, etc., water heating, and cooling purposes [7]. Cooling purposes alone are responsible for $15 \%$ of the total consumed energy. The fact that these types of devices will cause several damages to the surrounding environment

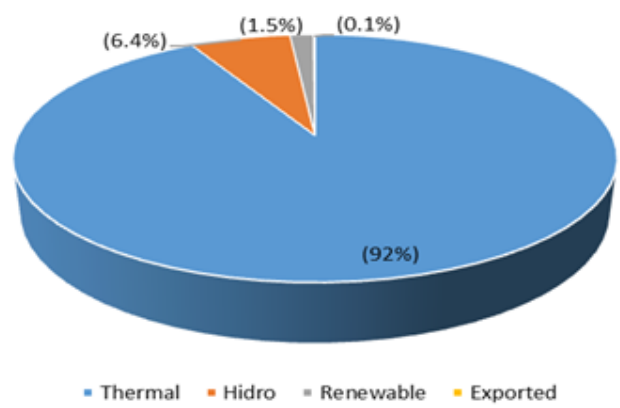

Figure 1- Generated energy from different sources 
can't be ignored. Hence, it's the architect's responsibility to find a way to replace these machines with natural cooling and ventilation systems [8].

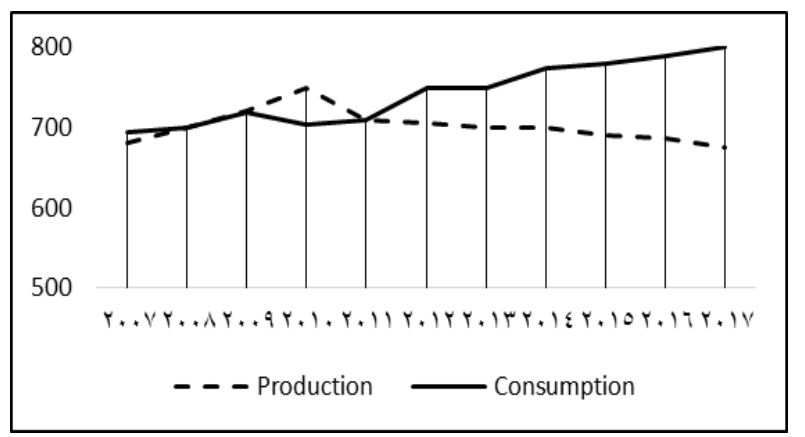

Figure 2- The gap between energy production \& consumption in Egypt

The situation in developing countries including Egypt is even worse since they are located in hot, dry climate zones, thus cooling energy represents almost $50 \%$ of the building energy consumption [7]. The main purpose of using cooling machines is to provide the building with the acceptable thermal comfort levels, which means reducing surrounding air temperature to become more suitable for the occupants. The amount of gained or lost heat in a room during a certain time period depends on the building's heat gain properties, which can be described in Equation (1).

$$
\rho \cdot \mathrm{C}_{\mathrm{p}} \cdot \mathrm{V} \cdot \frac{d T}{d t}=\mathrm{E}_{\mathrm{Int}}+\mathrm{E}_{\mathrm{Conv}}+\mathrm{E}_{\mathrm{Vent}}+\mathrm{E}_{\mathrm{Ac}}
$$

where:

$\begin{array}{ll}\rho \cdot \mathrm{C}_{\mathrm{p}} \cdot \mathrm{V} \cdot \frac{d T}{d t} \quad \begin{array}{l}\text { amount of gained or lost heat in a room } \\ \text { during a certain time period }(\mathrm{J} / \mathrm{S}) \\ \text { internal heat gain including direct solar } \\ \text { radiation }(\mathrm{J} / \mathrm{S})\end{array} \\ \mathrm{E}_{\text {Int: }} & \begin{array}{l}\text { heat gain and lose through the envelop } \\ (\mathrm{J} / \mathrm{S})\end{array} \\ \mathrm{E}_{\mathrm{Conv}}: & \begin{array}{l}\text { heat gain \& lose from and to external } \\ \text { environment }(\mathrm{J} / \mathrm{S}) \\ \text { heat gain \& lose from mechanical } \\ \mathrm{E}_{\mathrm{Vent}}:\end{array} \\ \mathrm{E}_{\mathrm{Ac}}: & \text { equipment }(\mathrm{J} / \mathrm{S})\end{array}$

From the above equation, it becomes clear that to decrease the energy consumption of a building, thermal comfort must be increased by reducing its heat gain, which can be reached by controlling one parameter or more from equation (1). As explained in Figure (3), two of these parameters represent the building envelope and its elements (walls, roofs, and windows). So, it can be said that to decrease the energy consumption of a building, it must modify or remodel its envelope to suit the surrounding environment $[9,10]$.

Roofs are considered one of the envelope's main elements since it protects the building from rain and solar radiation, which would be transmitted into the building. Because of its large surface area that is exposed to the sun all day, roofs present a chance to gain and lose a huge amount of solar radiation $[4,11]$. Roofs are responsible for $50-70 \%$ of building heat gain in a single-story building $[4,12]$. Due to its exposure to direct radiation all day, they receive a large amount of solar radiation. This quantity is magnified in flat and low-slope roofs. Passive techniques applied to roofs can affect greatly their thermal gain. So, choosing these techniques upon scientific bases is a vital thing. The main purpose of this search is to evaluate the effect of different roofing materials applied to a student housing building roof on energy consumption in hot dry climates.

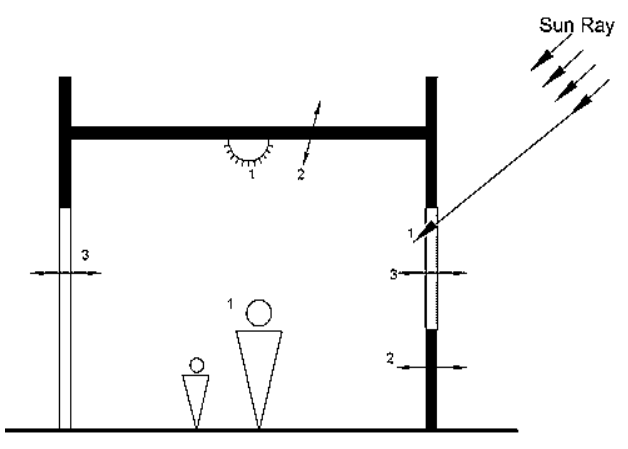

Figure 3- Heat gain in buildings

\section{RESEARCH SIGNIFICANCE}

The problem of Energy consumption usually increases in countries like Egypt because of the hot climate and the gap between its energy production and consumption. Reducing energy through passive cooling techniques can represent a perfect solution. However, such techniques are not studied widely in such countries. The authors believe that studying these techniques and evaluating their impact can lead the way towards expanding their use in building, to overcome the energy problems. This search presents the available passive cooling technique that can be used for buildings in Upper Egypt and an approach to apply building information modeling in energy simulation.

\section{LITERATURE REVIEW}

Many scientific papers studied passive techniques effect on building's energy consumption in different ways. The main objective of their studies was usually testing the effect of one or two different materials. There are some references studied cool and green roofs using DesignBuilder software [18, 20, 22], Also some of studies concentrated on three different kinds of cool roofs using Energy+ platform [21]. Others used the experimental study to test green roofs [26-28]. These studies and others differed according to the type of tested material, climate, and methodology, and all of them and others are illustrated in Table (1). Table (1) shows a lack of studies performed in hot-dry climates in general and the lack of using modern architectural concepts like Building Information Modeling (BIM) technique. Hot-dry climates should be the main concern, since they cover almost all the developing countries which usually have issues in energy consumption and generation like Egypt and the high population makes it worse. Thus, using modern engineering tools like BIM to improve building energy efficiency in developing countries, in particular, is encouraged. 
Table 1- Aims and scope of previous research work

\begin{tabular}{|c|c|c|c|}
\hline Ref. & Aim of the study & Methodology & Climate \\
\hline 13 & $\begin{array}{l}\text { Energy consumption } \& \text { thermal performance of PCM glazing units } \\
\text { on roofs. }\end{array}$ & Experimental study & $\mathrm{C}$ \\
\hline 14 & $\begin{array}{l}\text { Impact of } 3 \text { types of water-proofing materials (cool roofs) on } \\
\text { energy loads. }\end{array}$ & $\begin{array}{l}\text { Experimentally using test } \\
\text { box }\end{array}$ & HS \\
\hline 15 & Effect of cool roofs on indoor temperature. & $\begin{array}{l}\text { Simulation using TRNSYS } \\
\& \text { experimental case study }\end{array}$ & M \\
\hline 16 & Energy \& cost analyses of dynamic \& static cool roof. & Energy+ simulation & WC \\
\hline 17 & Energy consumption due to cool roofs, wall insulation \& glazing. & CFD ANSYS & $\mathrm{T}$ \\
\hline 4 & Cooling of cool roof with water- to-air heat exchanger. & Experimental case study & HD \\
\hline 18 & $\begin{array}{l}\text { Comparison between } 3 \text { types of roofs (traditional, cool and green } \\
\text { roofs) in terms of energy consumption and UHI and thermal stress } \\
\text { on roof. }\end{array}$ & $\begin{array}{l}\text { Simulation using } \\
\text { DesignBuilder }\end{array}$ & TEM \\
\hline 19 & $\begin{array}{l}\text { comparison between cool and green roof and their effect on urban } \\
\text { heat island and building energy consumption }\end{array}$ & $\begin{array}{l}\text { Simulation using Energy } \\
\text { Plus }\end{array}$ & M \\
\hline 20 & $\begin{array}{l}\text { Comparison between cool \& green roofs in terms of mitigating UHI } \\
\text { effect \& energy consumption. }\end{array}$ & $\begin{array}{l}\text { Simulation using } \\
\text { DesignBuilder }\end{array}$ & USA \\
\hline 21 & $\begin{array}{l}\text { Effect of } 3 \text { kinds of roofs (reflective roof, radiant barrier and } \\
\text { interior radiation control coating) on energy demand. }\end{array}$ & Simulation using Energy+ & HD \\
\hline 22 & Energy Saving due to two types of roofs, green and cool roofs. & $\begin{array}{l}\text { Simulation using Design } \\
\text { Builder }\end{array}$ & M \\
\hline 23 & $\begin{array}{l}\text { Effect of high reflective and high-emissive coatings on the building } \\
\text { energy performance. }\end{array}$ & $\begin{array}{l}\text { Experimental case study \& } \\
\text { simulation using Energy+ }\end{array}$ & M \\
\hline 24 & Green roofs effect on energy performance. & Mathematical model & TEM \\
\hline 25 & Green roofs effect on energy and cost saving. & $\begin{array}{l}\text { Simulation using Design } \\
\text { Builder }\end{array}$ & HD \\
\hline 26 & $\begin{array}{l}\text { Thermal behavior \& energy consumption of green roof. Energy } \\
\text { due to intensive, semi-intensive and extensive green roofs. }\end{array}$ & $\begin{array}{l}\text { Experimental case study \& } \\
\text { simulation using Energy+ }\end{array}$ & M \\
\hline 27 & Energy saving of green roof with night ventilation. & $\begin{array}{l}\text { Experimental case study \& } \\
\text { simulation using Energy+ }\end{array}$ & Hot \\
\hline 28 & Cooling potential of green roofs with a radiant cooling system & Experimental case study & HD \\
\hline 29 & $\begin{array}{l}\text { Effect of } 4 \text { types of green roofs on outdoor \& indoor temperature } \\
\text { and cooling demand }\end{array}$ & $\begin{array}{l}\text { Simulation using ENVI- } \\
\text { ment \& Energy+ }\end{array}$ & $\begin{array}{c}\text { HD } \\
\text { TEM }\end{array}$ \\
\hline 30 & Energy consumption of extensive green roofs & Experimental case study & $\mathrm{M}$ \\
\hline 31 & $\begin{array}{l}\text { Reducing cooling loads using new roof design combined of roof } \\
\text { pond \& low emission materials. }\end{array}$ & $\begin{array}{l}\text { Mathematical model } \\
\text { validated experimentally }\end{array}$ & HD \\
\hline 32 & $\begin{array}{l}\text { Energy consumption of a new roof pond design }(10-12 \mathrm{~cm} \text { depth } \\
\text { covered with } 15 \mathrm{~cm} \text { AL sheet above the pond for ventilation). }\end{array}$ & Experimental study & M \\
\hline 11 & $\begin{array}{l}\text { Water pond, water jacket and radiation shield compared in terms of } \\
\text { reducing cooling loads. }\end{array}$ & $\begin{array}{l}\text { Mathematical model } \\
\text { validated experimentally }\end{array}$ & $\mathrm{T}$ \\
\hline 33 & $\begin{array}{l}\text { Energy consumption and thermal comfort evolution for roof ponds } \\
\text { under different control methods. }\end{array}$ & TRNSYS simulation & Hot \\
\hline 34 & $\begin{array}{l}\text { Reducing cooling demand using double skin ventilated roof with } \\
\text { and without insulation. }\end{array}$ & CDF analyses & $\mathrm{T}$ \\
\hline 35 & $\begin{array}{l}\text { Indoor temperature due to different roofing materials (concrete, } \\
\text { white cement, broken white ceramics, clay coating) }\end{array}$ & Experimental case study & M \\
\hline
\end{tabular}

C: Cold, HS: Hot Season, M: Mediterranean, T: Tropical, HD: Hot-Dry, TEM: Temperature, WC: Worm \& Cold 
Through this review, many materials and techniques were introduced; all of them are reported in Table (2). In this regard, the main concern is to define the most effective and suitable one to be implemented in hot-dry climates in Upper Egypt.

Table 2- Different techniques studied inthe literature

\begin{tabular}{|l|l|}
\hline \multicolumn{1}{|c|}{ Reference } & \multicolumn{1}{c|}{ Technique } \\
\hline $11,31,32,36$ & Roof pond (different types ) \\
\hline $4,14,17,21,23$ & Cool roof (different materials) \\
\hline $18,20,22$ & Cool \& green \\
\hline 35 & Clay coating \\
\hline $24,8,30,37$ & $\begin{array}{l}\text { Green roof } \\
\text { (different plants \& designs) }\end{array}$ \\
\hline 13 & PCM \\
\hline 34 & $\begin{array}{l}\text { Double skin } \\
\text { (different designs) }\end{array}$ \\
\hline
\end{tabular}

\section{OBJECTIVES}

The objective of this research is to compare different passive cooling techniques applied to a student housing building in Upper hot arid areas in Egypt. The comparison included 31 variables shown in Table (3), the variables included green, cool, ponds, PCMs, insulation, clay, hollow block, double skin, and shaded roofs.

Table 3- Parameters of the current study

\begin{tabular}{|c|l|l|l|l|l|}
\hline Base case & F & DS & HB & PCM & I \\
\hline Hollow block & $\bullet$ & & & & $\bullet$ \\
\hline $\begin{array}{c}\text { Roof pond } \\
\text { (OPEN) }\end{array}$ & $\bullet$ & $\bullet$ & $\bullet$ & & $\bullet$ \\
\hline $\begin{array}{c}\text { Roof pond } \\
\text { (shaded) }\end{array}$ & $\bullet$ & & & & \\
\hline Cool roof & $\bullet$ & $\bullet$ & $\bullet$ & $\bullet$ & $\bullet$ \\
\hline Clay coating & $\bullet$ & $\bullet$ & $\bullet$ & $\bullet$ & $\bullet$ \\
\hline Green roof & $\bullet$ & & & & \\
\hline $\begin{array}{c}\text { Green roof } \\
\text { (always wet) }\end{array}$ & $\bullet$ & $\bullet$ & $\bullet$ & & $\bullet$ \\
\hline PCM & $\bullet$ & $\bullet$ & $\bullet$ & & \\
\hline $\begin{array}{c}\text { Insulations } \\
(12 \mathrm{~cm})\end{array}$ & $\bullet$ & $\bullet$ & $\bullet$ & $\bullet$ & \\
\hline $\begin{array}{c}\text { Double skin } \\
(10 \mathrm{~cm})\end{array}$ & $\bullet$ & & & & \\
\hline $\begin{array}{c}\text { Double skin } \\
(20 \mathrm{~cm})\end{array}$ & $\bullet$ & & & & \\
\hline
\end{tabular}

F: flat; DS: Double Skin; HB: Hollow block; I: Insolation

To compare the variables; a Building Information Modeling (BIM) model was developed using Revit for 3D modeling and Design-Builder for Energy simulation. The model was used to calculate energy consumption for the building in the default case without special heat isolation arrangements and with different variables applied.

The conducted simulation was used to calculate energy consumption for a student housing building in Upper Egypt and trying to decrease it to the minimum.
Decreasing energy consumption in these buildings is a considerable objective since it's a serving governmental building and a repeated building design model in the whole Egyptian universities. Thus, the findings of this search can be used to modify building regulations for this sort of buildings and similar ones. Not only the governmental building but also other kinds of buildings. Since Egypt is a developing country, it lacks energy legislation in general, and these kinds of researches help the government to set legislation upon a scientific foundation.

\section{METHODOLOGY}

A deductive approach was used first to make the review of the scientific papers in this regard. The aim of this review was to provide data for different passive cooling techniques that can be applied to the roof. From the review, it was defined the techniques that can be applied to the roof which illustrated in Figure (4).

The properties of the used materials are shown in Table (4). In addition to the review, a comparative applied study using BIM model for simulation was used in order to compare the different passive cooling techniques effect. The BIM model was used to identify both: the current state of the building, and the improvement due to the different passive techniques applied in terms of energy consumption.

Table 4- Properties of Insolation Materials

\begin{tabular}{|c|l|}
\hline Material & \multicolumn{1}{|c|}{ Properties } \\
\hline \multirow{3}{*}{$\begin{array}{c}\text { Reflective } \\
\text { material }\end{array}$} & Conductivity: $0.29 \mathrm{~W} / \mathrm{M} . \mathrm{K}$ \\
& Sensific heat: $1000 \mathrm{~J} / \mathrm{Kg} . \mathrm{K}$ \\
& Emissivity: 0.90 \\
& Solar absorbance: 0.40 \\
\hline & Plants height: $0.25 \mathrm{~m}$ \\
& Leaf area index: 4 \\
Green roof & Leaf reflectivity: 0.22 \\
vegetation & Leaf emissivity: 0.95 \\
& Minimum stomatal resistance: \\
& 120 S/M \\
\hline \multirow{3}{*}{ PCM } & Heat storage capacity: $148 \mathrm{~kJ} / \mathrm{kg}$ \\
& Specific heat: $2 \mathrm{~kJ} / \mathrm{kg} . \mathrm{k}$ \\
& Conductivity: $0.2 \mathrm{~W} / \mathrm{m} . \mathrm{K}$ \\
& Density (solid): $880 \mathrm{~kg} / \mathrm{m}^{3}$ \\
& Density (liquid): $760 \mathrm{~kg} / \mathrm{m}$ \\
\hline Expanded & Conductivity: $0.035 \mathrm{~W} / \mathrm{m} . \mathrm{K}$ \\
Peavyweight & Specific heat: $1400 \mathrm{~J} / \mathrm{kg} . \mathrm{K}$ \\
& Density: $25 \mathrm{~kg} / \mathrm{m}^{3}$ \\
\hline
\end{tabular}

The BIM model for energy simulation conducted using two software plus the BIM file format. The first software is to model the building into $3 \mathrm{D}$, the other one is the energy simulation software. In this study, the selected software are, Revit for 3D building model and DesignBuilder for energy simulation. The linkage between the two softwares was made using gbxml file format. Figure (5) illustrates the BIM model creation process. 

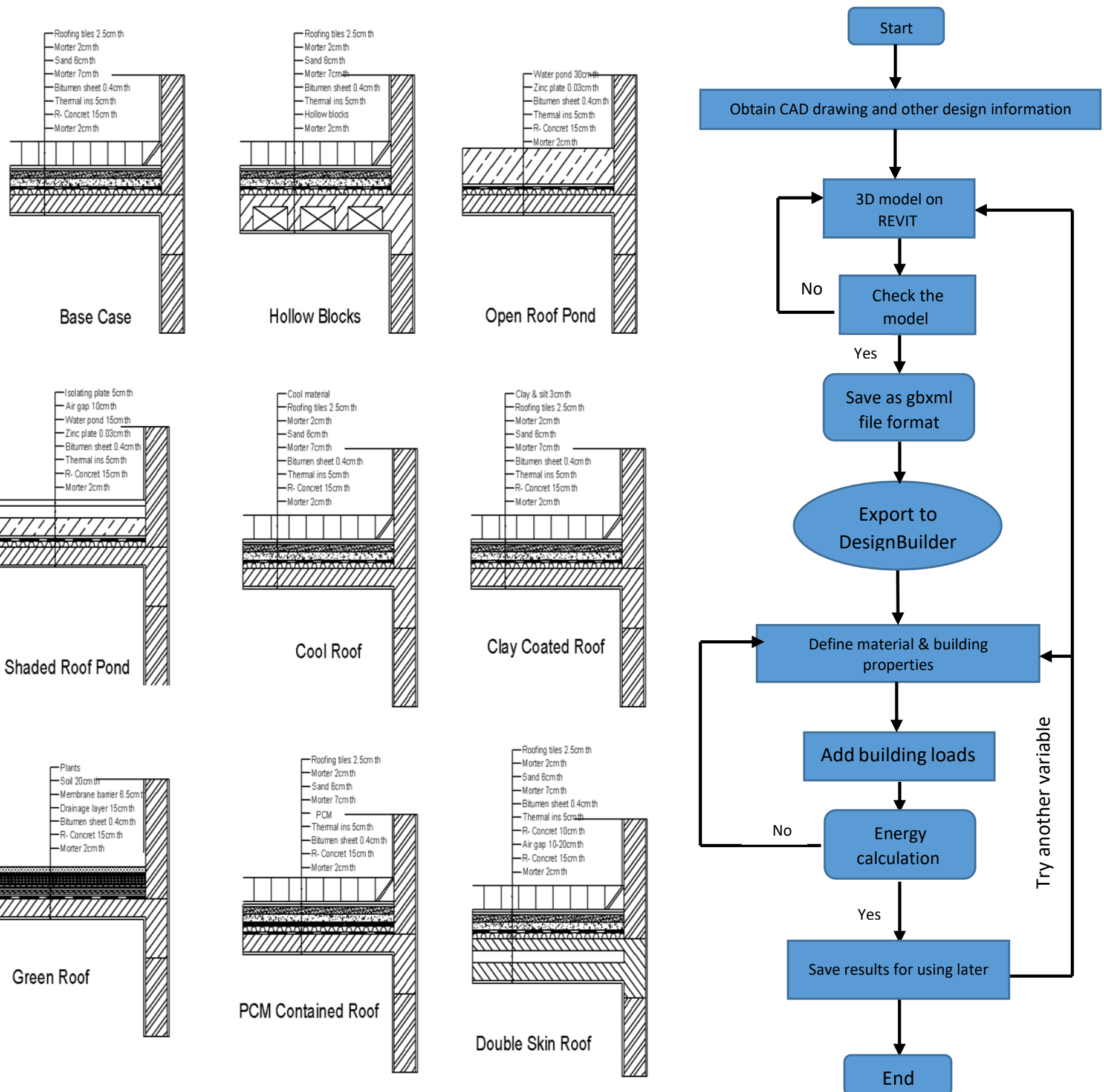

Figure 5- Different alternatives tested in the current study

Figure 6- flowchart shows using BIM in energy simulation

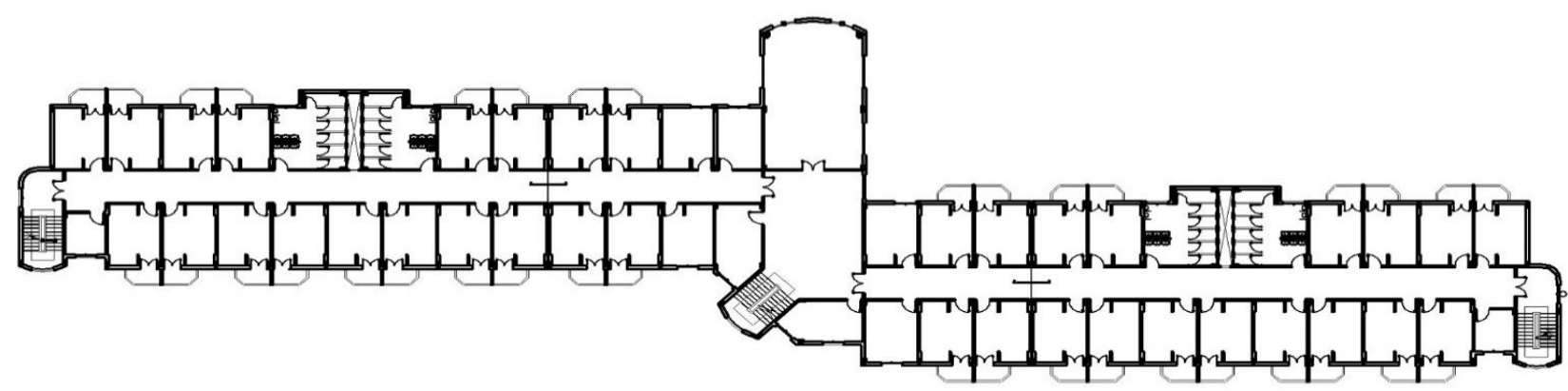

Figure 7- The last floor in the case study building (last floor) 


\section{Case study building}

Building description: The case study building is a student housing building, which belongs to Sohag University, Egypt. The building is 5 floors rise, with a basement. The ground floor is an office floor, all upper floors are student rooms. The basement contains the kitchen, restaurant, and study rooms. In this study, it will be taken only one floor from the building, which is the last one since this study the roof and student rooms are a repeated unit in the building. Figure (6) illustrates the floor we're going to study.

To identify the building properties, the building was visited and plan measurements were recorded. All observed properties are introduced in Table (5).

Table 5- Case study building properties

\begin{tabular}{|c|c|}
\hline Property & Base Case \\
\hline Orientation & North \\
\hline Building shape & A rectangle \\
\hline Floor height & $3.20 \mathrm{~m}$ \\
\hline External wall & $\begin{array}{l}\text { A } 12 \mathrm{~cm} \text { perforated clay brick in } \\
\text { addition to two layer of mortar each } \\
2 \mathrm{~cm} \text { on each side }\end{array}$ \\
\hline Opening area & $\begin{array}{l}\text { There is no windows in the room - } \\
\text { Balcony door area } 2.64 \mathrm{~m}^{2}\end{array}$ \\
\hline Occupancy & 4 student in each room \\
\hline Lighting & $\begin{array}{l}\text { Each room has two lighting device } \\
\text { each one contain } 2 \text { fluorescent lamb } \\
120 \mathrm{~cm} \text { long and } 40 \text { watt }\end{array}$ \\
\hline $\begin{array}{l}\text { Equipment and } \\
\text { devices }\end{array}$ & No equipment or devices in the room \\
\hline $\begin{array}{l}\text { Cooling } \\
\text { temperature }\end{array}$ & 23 Celsius \\
\hline Weather data file & Energy+ weather data \\
\hline $\begin{array}{l}\text { Building } \\
\text { operation } \\
\text { schedule }\end{array}$ & $\begin{array}{l}\text { The students were presumed to be } \\
50 \% \text { in the lecture time, from } 8 \text { am to } \\
2 \mathrm{pm} \text {. The rest of the time was } 100 \% \\
\text { and the students were not available } \\
\text { during the summer period for three } \\
\text { months. }\end{array}$ \\
\hline
\end{tabular}

Location and climate: The building is located in New Sohag city in Sohag governorate in South Egypt, It is surrounded by the desert from all directions Figure (7). The climate in this region is divided into two seasons: winter which lasts for three months and summer which lasts the rest of the year. Temperature during summer ranges between 40-49 oC, while in winter it's between 2026 oC. Moisture is usually low, it starts at $10 \%$ and may reach $55 \%$ in some cases. Rain is rare in this region, the rainfall average is $55 \mathrm{~mm}$ per year and rarely reach $55 \mathrm{~mm}$ in an hour.
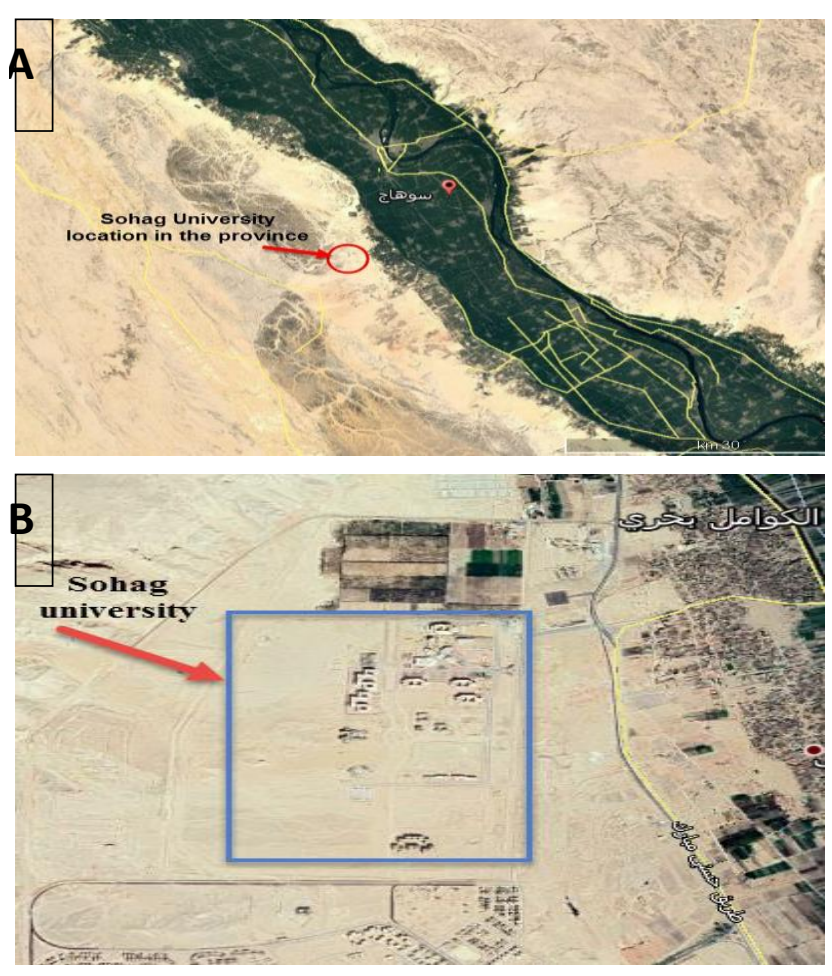

Figure 7- A the building location in the governorate \& B Sohag university layout

\section{RESULTS AND DISSCUSION}

Applying different techniques on the building roof showed a noticeable impact. The effect of each technique will be illustrated, then the effect of applying more than one technique will be explained. In general, the effect of all techniques is quiet noticeable in Summer, which is expected since temperatures are higher in this season.

The annual energy consumption for the building in the base case is $101830 \mathrm{KWH}$. When hollow blocks were used in the structural system of the roof, the annual energy consumption was reduced by $11.6 \%$ to reach $89946 \mathrm{KWH}$. This reduction is especially highlighted during Summer periods illustrated in Figure (8). Unlike hollow blocks, roof ponds achieved only $5.1 \%$ reduction in energy consumption, with $96627 \mathrm{KWH}$ annual consumption, as shown in Figure (9).

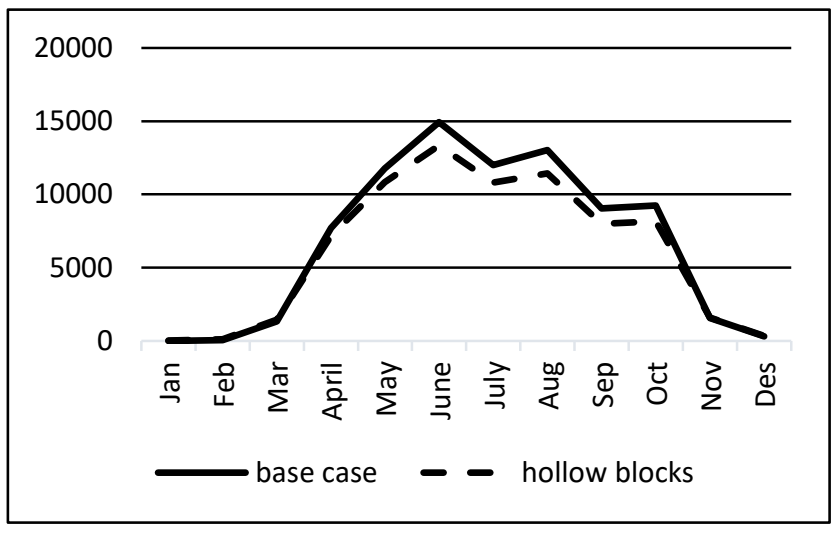

Figure 8- Difference in monthly energy consumption between base case \& hollow blocks 


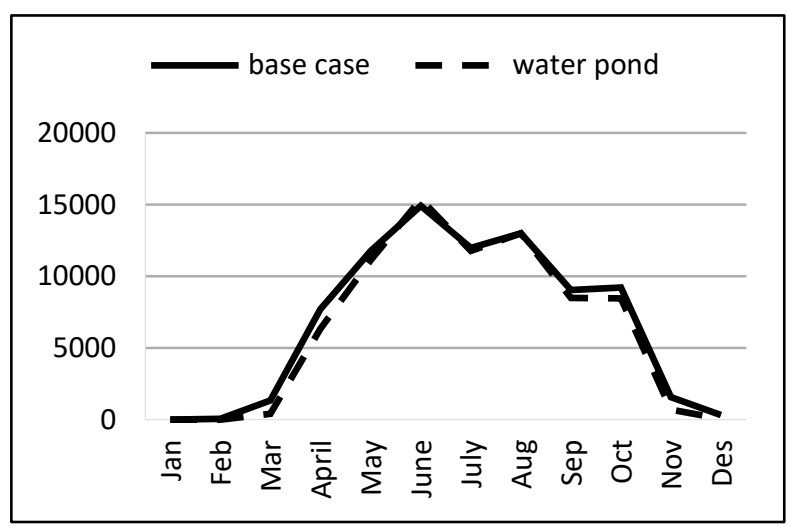

Figure 9- Difference in the monthly energy consumption between roof pond \& base case

Shaded roof ponds were even better, since the annual energy consumption reached $87182 \mathrm{KWH}$, with $14.3 \%$ reduction. Figure (10) shows the building monthly consumption. Cool roofs were also in the same range, their annual savings were $14.5 \%$, with 87219 KWH consumption as seen in Figure (11). Clay coating on the other side has a relatively small effect since the building's energy consumption achieved $96648 \mathrm{KWH}$. This amount is so close to the roof pond technique. Figure (12) shows this case of energy consumption over the months.

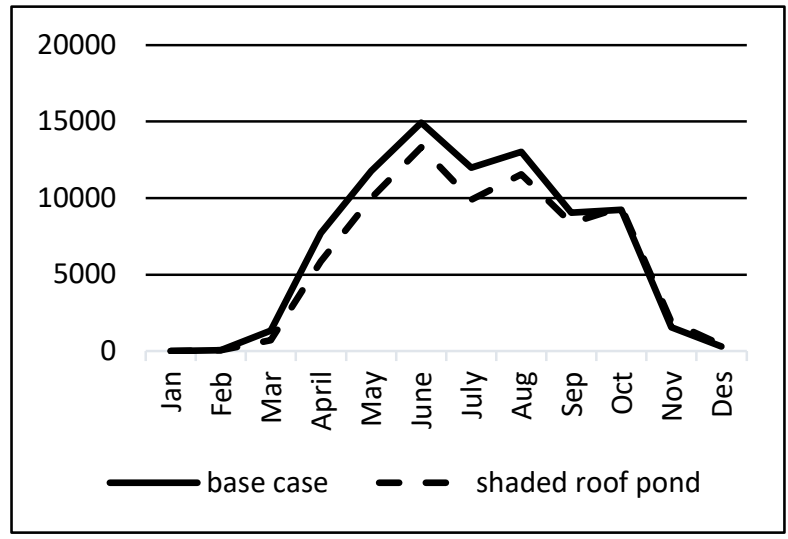

Figure 10- Difference in month's energy consumption between base case and shaded roof ponds

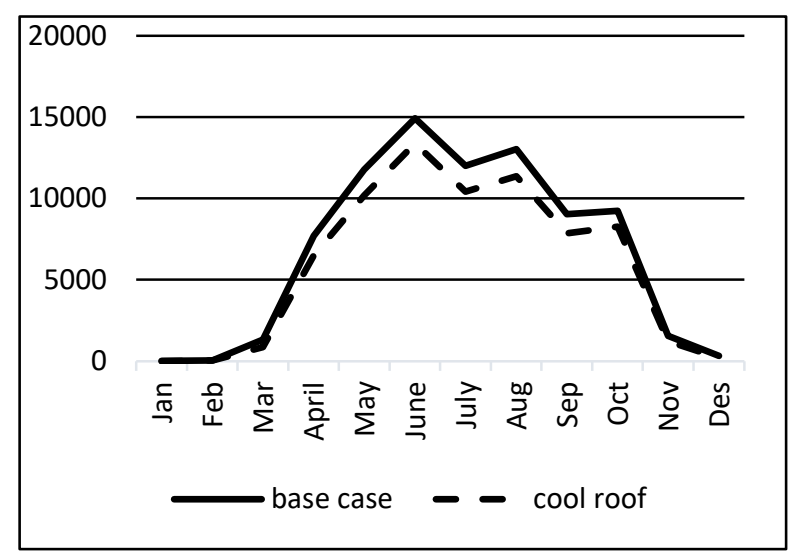

Figure 11- Difference in energy consumption between base case and cool roofs

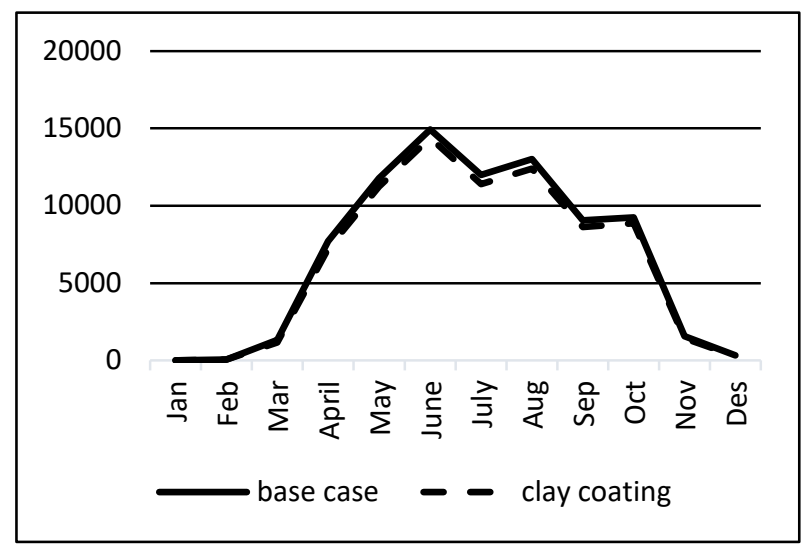

Figure 12- Difference in monthly energy consumption between base case $\&$ clay coating

Green roofs showed the best effect among all techniques, in the first case, this study applied green roofs with no irrigation schedule. The annual energy consumption, in this case, was 60056 , with $41 \%$ reduction in energy consumption. But when using the irrigation schedule, the energy consumption decreased to $39028 \mathrm{KWH}$ which represents $61 \%$ saving in the consumed energy. Figure (13) illustrates the difference in energy consumption for the 3 cases.

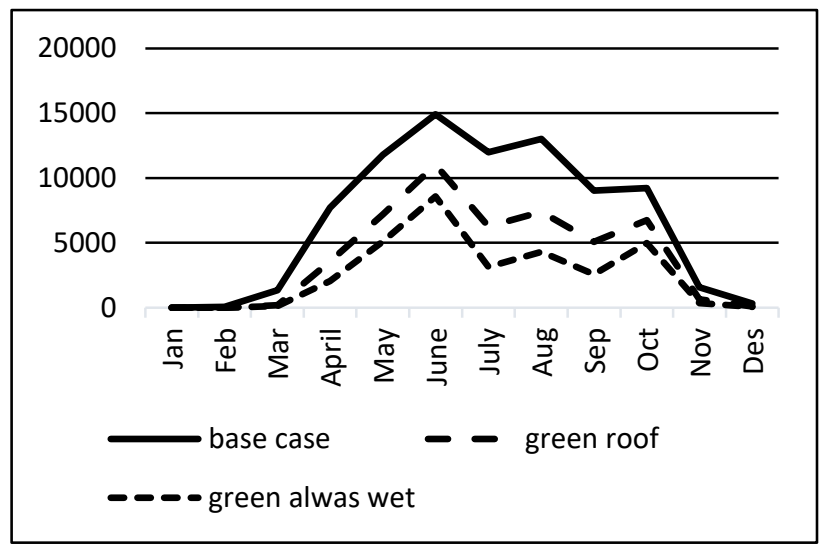

Figure 13- Difference in energy consumption between base case, green roof, and green roof always wet

Using Phase Change Materials (PCM) in the roof was better than cool and clay-coated roofs. The annual energy consumption for this case was $76689 \mathrm{KWH}$, and that is about $24 \%$ saving in energy as shown in Figure (14). On the other hand, using double-skin roofs as a technique was of a little influence. Two gap-sizes of 10 and $20 \mathrm{~cm}$ were considered and examined in this technique. The difference in energy consumption between the two cases was small. The $10 \mathrm{~cm}$ air gap reduced energy consumption to 98295 $\mathrm{KWH}$, while the $20 \mathrm{~cm}$ air gap achieved $97893 \mathrm{KWH}$, the difference between the two cases is about $0.5 \%$ increase in energy savings, as illustrated in Figure (15) the cases are almost identical. 


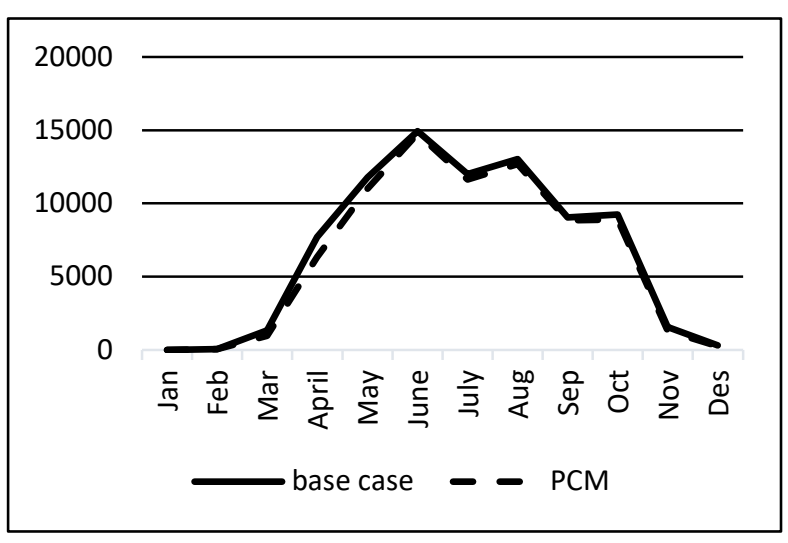

Figure 14- Difference in energy consumption between base case and PCM

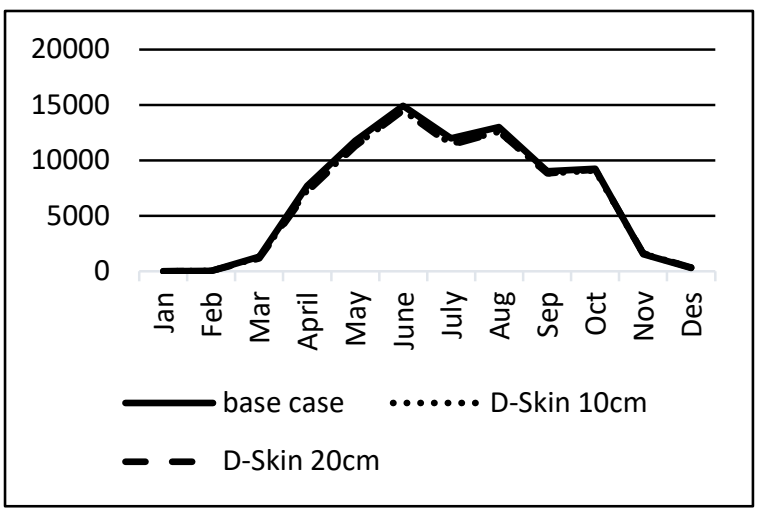

Figure 15- Difference in energy consumption between (base case, $10 \mathrm{~cm}$, and $20 \mathrm{~cm}$ air gap)
Increasing insulation thickness was also an effective way to reduce energy. The annual consumption savings for the building was reduced by $16 \%$ due to increased insulation. This highlights the importance of this technique since it's cheap, available, and not complicated.

The annual energy consumption of the building decreased by different ratios according to the applied technique. The highest energy saving occurred when applying green roofs with the irrigation schedule. Where the minimum effect occurred in the clay coating. Figure (16) compares the effect of all techniques applied to the roof.

Combining more than one technique was even better, merging green roofs and increased insulation achieved $46 \%$ saving in energy consumption. While hollow blocks with green roofs were less effective, they only reduced energy by $41.5 \%$ with $0.5 \%$ improvement than green roofs only. Cool roofs and PCM also represent a good choice since they reduced energy by $18 \%$. The same percentage achieved using cool roofs and hollow blocks. Figure (17) shows the different influences of each combination.

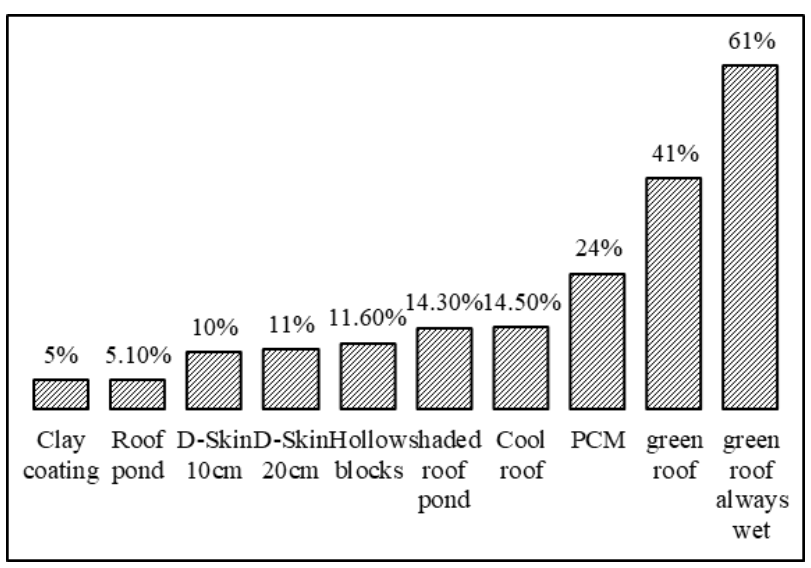

Figure 16- Effect of different techniques on the annual energy consumption of the building

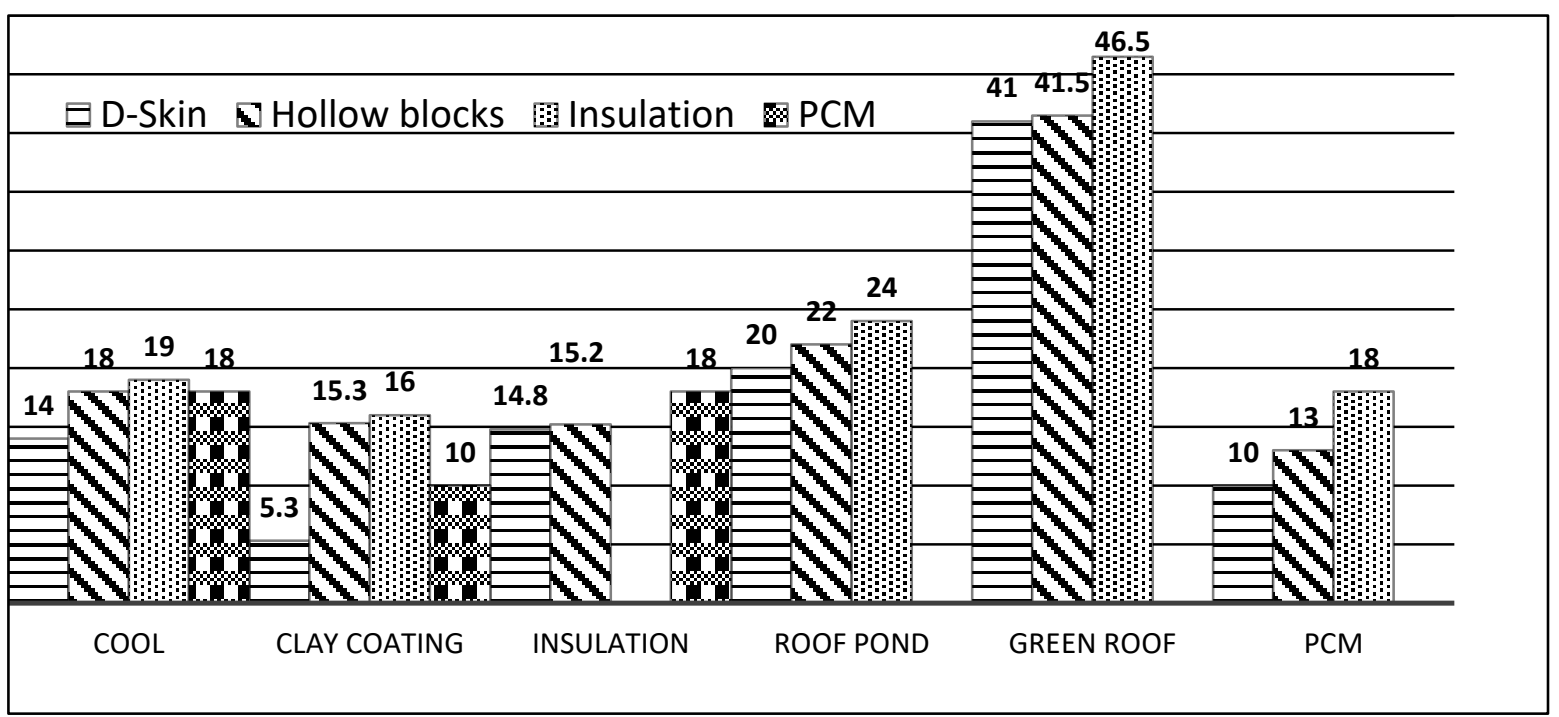

Figure 17- Effect of different combinations of passive techniques on the building's energy consumption 


\section{CONCLUSIONS}

In this search 31 passive cooling techniques applied to a student housing building roof in Upper Egypt in terms of energy consumption were compared. Green roofs were found to be the most effective technique since it saves about $41 \%$ of the energy consumed in the building. Merging more than one technique was more effective, and green roofs achieved a remarkable saving in energy consumption in the building. From the above, the researchers conclude that:

- Energy design in Egypt should earn more concern due to the current energy situation.

- Using BIM in energy design is an effective tool that should be used in construction industry in Egypt.

- Passive cooling techniques could represent a good chance to improve the energy situation and thermal comfort.

- Government legislation should include using passive techniques in such areas.

- Committing the construction industry members to design energy in new buildings.

- Creating databases for the new passive cooling techniques to help engineers in making decision. This databases must include the technique materials, its properties, how to implement, maintenance, and the related scientific researches.

- Expanding green roofs usage - in particular - in hot arid areas should be a government legislation.

\section{REFERENCES}

[1] D. Yeom and P. La Roche, "Investigation on the cooling performance of a green roof with a radiant cooling system," Energy Build., vol. 149, pp. 26-37, 2017, doi: 10.1016/j.enbuild.2017.05.035.

[2] C. Piselli, V. L. Castaldo, and A. L. Pisello, "How to enhance thermal energy storage effect of PCM in roofs with varying solar reflectance: Experimental and numerical assessment of a new roof system for passive cooling in different climate conditions," Sol. Energy, no. December 2017, pp. 0-1, 2018, doi: 10.1016/j.solener.2018.06.047.

[3] A. Sharifi and Y. Yamagata, "Roof ponds as passive heating and cooling systems: A systematic review," Appl. Energy, vol. 160, pp. 336-357, 2015, doi: 10.1016/j.apenergy.2015.09.061.

[4] J. M. Almodovar and P. La Roche, "Roof ponds combined with a water-to-air heat exchanger as a passive cooling system: Experimental comparison of two system variants," Renew. Energy, vol. 141, pp. 195-208, 2019, doi: 10.1016/j.renene.2019.03.148.
[6] Energypedia survey, "Egyption energy situation."

[7] I. Oropeza-Perez and P. A. Østergaard, "Active and passive cooling methods for dwellings: A review," Renew. Sustain. Energy Rev., vol. 82, no. July 2016, pp. 531-544, 2018, doi: 10.1016/j.rser.2017.09.059.

[8] A. H. Poshtiri, S. Bahar, and A. Jafari, "Daily cooling of one-story buildings using domed roof and solar adsorption cooling system," Appl. Energy, vol. 182, pp. 299-319, 2016, doi:

10.1016/j.apenergy.2016.08.132.

[9] A. Gagliano, F. Patania, F. Nocera, A. Ferlito, and A. Galesi, "Thermal performance of ventilated roofs during summer period," Energy Build., vol. 49, pp. 611-618, 2012, doi: 10.1016/j.enbuild.2012.03.007.

[10] H. Fang et al., "Performance evaluation of a metamaterial-based new cool roof using improved Roof Thermal Transfer Value model," Appl. Energy, vol. 248, no. December 2018, pp. 589-599, 2019, doi: 10.1016/j.apenergy.2019.04.116.

[11] D. Sabzi, P. Haseli, M. Jafarian, G. Karimi, and M. Taheri, "Investigation of cooling load reduction in buildings by passive cooling options applied on roof," Energy Build., vol. 109, pp. 135-142, 2015, doi: 10.1016/j.enbuild.2015.09.042.

[12] K. M. Al-Obaidi, M. Ismail, and A. M. Abdul Rahman, "Passive cooling techniques through reflective and radiative roofs in tropical houses in Southeast Asia: A literature review," Front. Archit. Res., vol. 3, no. 3, pp. 283-297, 2014, doi: 10.1016/j.foar.2014.06.002.

[13] D. Li, Y. Wu, G. Zhang, M. Arıcı, C. Liu, and F. Wang, "Influence of glazed roof containing phase change material on indoor thermal environment and energy consumption," Appl. Energy, vol. 222, no. April, pp. 343-350, 2018, doi: 10.1016/j.apenergy.2018.04.015.

[14] I. Hernández-Pérez, I. Zavala-Guillén, J. Xamán, J. M. Belman-Flores, E. V. Macias-Melo, and K. M. Aguilar-Castro, "Test box experiment to assess the impact of waterproofing materials on the energy gain of building roofs in Mexico," Energy, vol. 186, no. 2019, p. 115847, 2019, doi: 10.1016/j.energy.2019.07.177.

[15] E. Bozonnet, M. Doya, and F. Allard, "Cool roofs impact on building thermal response: A French case study," Energy Build., vol. 43, no. 11, pp. 30063012, 2011, doi: 10.1016/j.enbuild.2011.07.017.

[16] J. Testa and M. Krarti, "Evaluation of energy savings potential of variable reflective roofing systems for US buildings," Sustain. Cities Soc., vol. 31, pp. 6273, 2017, doi: 10.1016/j.scs.2017.01.016.

[5] Egyptian energy ministry, "Energy annual report," 2018. . 
[17] V. K. Venkiteswaran, J. Liman, and S. A. Alkaff, "Comparative Study of Passive Methods for Reducing Cooling Load," Energy Procedia, vol. 142, pp. 2689-2697, 2017, doi:

10.1016/j.egypro.2017.12.212.

[18] A. Gagliano, M. Detommaso, F. Nocera, and G. Evola, "A multi-criteria methodology for comparing the energy and environmental behavior of cool, green and traditional roofs," Build. Environ., vol. 90, pp. 71-81, 2015, doi: 10.1016/j.buildenv.2015.02.043.

[19] V. Costanzo, G. Evola, and L. Marletta, "Energy savings in buildings or UHI mitigation? Comparison between green roofs and cool roofs," Energy Build., vol. 114, pp. 247-255, 2016, doi:

10.1016/j.enbuild.2015.04.053.

[20] K. K. Roman, T. O’Brien, J. B. Alvey, and O. J. Woo, "Simulating the effects of cool roof and PCM (phase change materials) based roof to mitigate UHI (urban heat island) in prominent US cities," Energy, vol. 96, pp. 103-117, 2016, doi: 10.1016/j.energy.2015.11.082.

[21] H. I. Mohamed, J. Lee, and J. D. Chang, "The Effect of Exterior and Interior Roof Thermal Radiation on Buildings Cooling Energy," Procedia Eng., vol. 145, pp. 987-994, 2016, doi: 10.1016/j.proeng.2016.04.128.

[22] M. Zinzi and S. Agnoli, "Cool and green roofs. An energy and comfort comparison between passive cooling and mitigation urban heat island techniques for residential buildings in the Mediterranean region," Energy Build., vol. 55, pp. 66-76, 2012, doi: 10.1016/j.enbuild.2011.09.024.

[23] F. Ascione, R. F. De Masi, M. Santamouris, S. Ruggiero, and G. P. Vanoli, "Experimental and numerical evaluations on the energy penalty of reflective roofs during the heating season for Mediterranean climate," Energy, vol. 144, pp. 178199, 2018, doi: 10.1016/j.energy.2017.12.018.

[24] I. Jaffal, S. E. Ouldboukhitine, and R. Belarbi, “A comprehensive study of the impact of green roofs on building energy performance," Renew. Energy, vol. 43, pp. 157-164, 2012, doi: 10.1016/j.renene.2011.12.004.

[25] B. Kamel, S. Wahba, K. Nassar, and A. Abdelsalam, "Effectiveness of Green-Roof on Reducing Energy Consumption through Simulation Program for a Residential Building: Cairo, Egypt," no. December 2014, pp. 1740-1749, 2012, doi: 10.1061/9780784412329.175.

[26] C. M. Silva, M. G. Gomes, and M. Silva, "Green roofs energy performance in Mediterranean climate," Energy Build., vol. 116, pp. 318-325, 2016, doi: 10.1016/j.enbuild.2016.01.012.
[27] L. Jiang and M. Tang, "Thermal analysis of extensive green roofs combined with night ventilation for space cooling," Energy Build., vol. 156, pp. 238-249, 2017, doi: 10.1016/j.enbuild.2017.09.080.

[28] D. Yeom and P. La Roche, "Investigation on the cooling performance of a green roof with a radiant cooling system," Energy Build., vol. 149, pp. 26-37, 2017, doi: 10.1016/j.enbuild.2017.05.035.

[29] T. E. Morakinyo, K. W. D. Kalani, C. Dahanayake, E. Ng, and C. L. Chow, "Temperature and cooling demand reduction by green-roof types in different climates and urban densities: A co-simulation parametric study," Energy Build., vol. 145, pp. 226237, 2017, doi: 10.1016/j.enbuild.2017.03.066.

[30] P. Piro, M. Carbone, M. De Simone, M. Maiolo, P. Bevilacqua, and N. Arcuri, "Energy and hydraulic performance of a vegetated roof in sub-mediterranean climate," Sustain., vol. 10, no. 10, pp. 1-13, 2018, doi: 10.3390/su10103473.

[31] I. Dincer, A. Midilli, and H. Kucuk, "Progress in exergy, energy, and the environment," Prog. Exergy, Energy, Environ., pp. 1-1086, 2014, doi: 10.1007/978-3-319-04681-5.

[32] A. Spanaki, D. Kolokotsa, T. Tsoutsos, and I. Zacharopoulos, "Assessing the passive cooling effect of the ventilated pond protected with a reflecting layer," Appl. Energy, vol. 123, pp. 273-280, 2014, doi: 10.1016/j.apenergy.2014.02.040.

[33] Y. Li, Z. Zhuang, Q. Zhu, J. Song, and H. An, "Research on control methods of roof radiant cooling system," Procedia Eng., vol. 205, pp. 2149-2155, 2017, doi: 10.1016/j.proeng.2017.10.143.

[34] A. I. Omar, J. Virgone, E. Vergnault, D. David, and A. I. Idriss, "Energy Saving Potential with a DoubleSkin Roof Ventilated by Natural Convection in Djibouti," Energy Procedia, vol. 140, pp. 361-373, 2017, doi: 10.1016/j.egypro.2017.11.149.

[35] M. A. Hamdan, J. Yamin, and E. M. Abdel Hafez, "Passive cooling roof design under Jordanian climate," Sustain. Cities Soc., vol. 5, no. 1, pp. 2629, 2012, doi: 10.1016/j.scs.2011.10.004.

[36] Y. Li, Z. Zhuang, Q. Zhu, J. Song, and H. An, "Research on control methods of roof radiant cooling system," Procedia Eng., vol. 205, pp. 2149-2155, 2017, doi: 10.1016/j.proeng.2017.10.143.

[37] T. E. Morakinyo, K. W. D. Kalani, C. Dahanayake, E. $\mathrm{Ng}$, and C. L. Chow, "Temperature and cooling demand reduction by green-roof types in different climates and urban densities: A co-simulation parametric study," Energy Build., vol. 145, pp. 226237, 2017, doi: 10.1016/j.enbuild.2017.03.066. 